\title{
EFEKTIFITAS METODE MENGAJAR KESELURUHAN DENGAN METODE MENGAJAR BAGIAN PERBAGIAN TERHADAP HASIL BELAJAR MENGUMPAN (PASSING) KAKI BAGIAN DALAM PADA PERMAINAN FUTSAL MAHASISWA FIK UNM
}

\author{
Sudirman $^{1}$, Andi Mas Jaya ${ }^{2}$
}

\section{Keywords :}

Metode; Mengajar

Keseluruhan; Mengajar

Bagian; Hasil Belajar;

Passing Futsal.

\author{
Corespondensi Author \\ ${ }^{1}$ Pendidikan Jasmani \\ Kesehatan dan Rekreasi, \\ Universitas Negeri Makassar, \\ sudirman@unm.ac.id \\ ${ }^{2}$ Pendidikan Jasmani \\ Kesehatan dan Rekreasi, \\ Universitas Negeri Makassar, \\ andi.mas.jaya@unm.ac.id
}

\section{Article History \\ Received: Desember 2019; \\ Reviewed: Januari 2020; \\ Accepted: Januari 2020; \\ Published: Februari 2020}

\begin{abstract}
This study aims to find out which is more effective between the overall method and the teaching method part by section on learning outcomes passing (passing) the inner leg in students who take Futsal learning. This research was carried out by an experimental method in total sampling. The data analysis technique used to test the hypothesis is the t-test, at a significant level $\alpha=0.05$, starting with calculating the t-count value to compare with the t-table value at a significant level of $95 \%$. (1) The whole method is obtained by tcount $=4$, the value listed in $t$-table with degrees of freedom $(d k)=$ $15-1=14$. A significant level of $5 \%$ is 2.14 , so t-count $>$ t-table, means that there is a convincing (significant) difference before and after being given the overall method treatment. (2) The teaching method part of division is obtained the value of $t$-count $=3.7$, the value listed in t-table with degrees of freedom $(d k)=15-1=14$. Significant level of 5\% is 2.14, so t-count $>$ t-table, means that there is a convincing (significant) difference before and after the treatment method is given in part. And (3) The overall method and the partby-part teaching method obtained t-count $=3.2$, the values listed in t-table with degrees of freedom $(d k)=15+15-2=28$. A significant level of $5 \%$ is 2.05. So t-count $>t$-table.
\end{abstract}
ABSTRAK
Penelitian ini bertujuan untuk mengetahui mana yang lebih efektif antara metode keseluruhan dengan metode mengajar bagian perbagian terhadap hasil belajar mengumpan (passing) kaki bagian dalam pada mahasiswa yang mengikuti pembelajaran Futsal. Penelitian ini dilakukan dengan metode eksperimen secara total sampling. Teknik analisis data yang dipergunakan untuk menguji hipotesis adalah uji-t, pada taraf signifikan $\alpha 0,05$, dimulai dengan menghitung nilai t-hitung untuk membandingkan dengan nilai t- tabel pada taraf signifikan 95\%. (1) Metode keseluruhan diperoleh nilai t-hitung $=4$, nilai yang tercantum dalam t-tabel dengan derajat kebebasan $(d k)=15-1=14$. Taraf signifikan 5\% adalah 2,14, jadi t-hitung > t-tabel, berarti ada perbedaan yang meyakinkan (signifikan) sebelum dan setelah diberikan perlakuan metode keseluruhan. (2) Metode mengajar bagian perbagian diperoleh nilai t-hitung $=3,7$, nilai yang tercantum dalam t-tabel 
dengan derajat kebebasan (dk) $=15-1=14$. Taraf signifikan 5\% adalah 2,14, jadi t-hitung $>$ t-tabel, berarti ada perbedaan yang meyakinkan (signifikan) sebelum dan setelah diberikan perlakuan metode mengajar bagian perbagian. Dan (3) Metode keseluruhan dan metode mengajar bagian perbagian diperoleh nilai t-hitung $=3,2$, nilai yang tercantum dalam $t$-tabel dengan derajat kebebasan (dk) $=15+15-2=28$. Taraf signifikan $95 \%$ adalah 2,05. Jadi $t$ hitung $>$ t-tabel.

\section{PENDAHULUAN}

Futsal identik dengan permainan sepak bola, hanya yang membedakan keduanya adalah sisi lapangan, peraturan, jumlah pemain, dan cara bermain, Futsal tidak mengenal panas ataupun hujan. Dikarenakan tempatnya terbatas, permainan Futsal membutuhkan kecepatan berpikir dalam melakukan operan yang akurat dan juga stamina yang bagus, dalam permainan Futsal harus baik dalam mempertimbangkan penggunaan teknik ketika masing-masing pemain. Futsal adalah permainan sangat cepat dan dinamis oleh karena itu diperlukan kerja sama antar pemain lewat passing yang keras dan akurat. Dan banyaknya jenis keterampilan passing yang digunakan dalam menguasai bola ketika melakukan serangan, lawan akan sulit dalam melakukan organisasi pertahanan daerah gawangnya. Kadir Yusuf (1982:31) mengatakan bahwa, bermain bola sebenarnya sederhana sekali, yakni bagaimana kita bisa kompak bertahan pada saat kehilangan bola dan bagaimana bisa kompak menyerang pada saat menguasai bola. Mengumpan lebih efisien dari pada menggiring, bahwa bermain Futsal yang baik adalah selalu mengumpan bola kepada kawan sebelum bola direbut lawan, sehingga bola yang diumpan dapat diterima oleh kawan dengan mudah tanpa direbut lawan. Seorang pemain yang memiliki keterampilan passing yang baik adalah pemain yang melakukan passing tepat ke arah yang dituju tanpa menyusahkan rekan satu tim yang menerima. Seperti yang dikemukakan oleh Gerhard Bauer bahwa kualitas atau mutu dari passing menentukan keberhasilan dalam permainan kombinasi. Operan yang baik adalah inti dari Futsal atau sepak bola, tetapi ada beberapa pilihan yang harus ditentukan sebelum mengoper. Pada saat menguasai bola dan memulai suatu serangan dalam Futsal membutuhkan kualitas passing yang baik dan harus sering dilatih. Untuk menguasai keterampilan passing diperlukan penguasaan gerakan sehingga sasaran yang diinginkan tercapai.

Menurut John D. Tenang (2008) Futsal merupakan suatu permainan yang mengutamakan operan-operan pendek atau istilah Passing Game, karena seorang pemain harus menguasai teknik mengumpan atau operan bola yang benar. Passing dalam sebuah permainan Futsal banyak jenisnya ada passing dekat, passing jauh, passing mendatar, passing melambung, passing satu atau dua kali sentuh, passing yang mematikan, passing melengkung dan lain-lain. Yang paling pokok dari semua jenis passing itu adalah mudah diterima rekan satu tim tanpa ia bersusuah payah. Karena passing yang baik adalah passing yang mampu kita tujukan ke arah sasaran dengan teknik yang benar. Untuk dapat melakukan passing dengan baik dan benar pemain Futsal harus mengetahui teknik dasar dalam melakukannya, hal ini erat hubungannya dengan pelaksanaan di lapangan. Dalam permainan Futsal teknik mengoper bola passing yang dominan dengan menggunakan kaki bagian dalam agar mudah untuk mengarahkan ke kawan pada saat tim menguasai bola, dengan situasi lapangan yang kecil mengoper bola passing harus tepat di kaki, apabila tidak tepat di kaki maka lawan akan mudah merebutnya. Keterampilan passing bola yang benar dan harus siswa pelajari terlebih dahulu biasanya disebut dengan push pass (operan dorongan) karena bagian samping kaki sebenarnya mendorong bola. Menendang adalah salah satu skill dasar permainan Futsal yang sangat dibutuhkan oleh setiap pemain, sebab hampir sebagian besar pemain Futsal menggunakan tendangan atau menendang. Dalam hal ini adalah tendangan yang bertujuan untuk passing ke arah teman, passing yang baik adalah ketepatan dalam melakukan 


\section{e-ISSN: 2657-0703 dan p-ISSN: 2085-5389}

tendangan bola ke arah sasaran yang diinginkan. Adapun Menurut John D. Tenang (2008), terdapat tiga teknik dasar dalam mengoper bola, yaitu: (1) Dengan kaki bagian dalam (Inside of the foot), (2) Dengan kaki bagian luar (Outside of the foot), dan (3) Dengan punggung kaki (Instep of the foot).

Teknik dasar passing kaki bagian dalam. Yaitu hanya passing yang menggunakan kaki bagian dalam. Bagian dalam kaki adalah bagian yang paling sering digunakan untuk menendang bola. Bagian kaki tersebut memiliki permukaan yang paling luas untuk menendang bola dibandingkan bagian lain, sehingga lebih mudah bagi siswa untuk menembak ke arah bola jika siswa menendangnya, sehingga sangat ideal untuk melakukan operan yang akurat. Menurut Gill Harvey (2003) definisi passing kaki bagian dalam adalah: Passing menggunkan kaki bagian dalam adalah dimana posisi kaki tumpu sejajar dan dekat dengan bola, lutut kaki sedikit ditekuk, dengan lutut berputar arah keluar, posisi badan berada di atas bola (menutup), tangan membentang kesamping untuk menjaga keseimbangan tubuh. Ketika bola ditendang pada bagian tengah-tengah bola lalu diikuti gerakan lanjutan. Sedangkan Joseph A. Luxbacher (1997), definisi passing kaki bagian dalam sebagai berikut: Passing menggunkan kaki bagian dalam adalah ketika berdiri menghadap kedepan letakan kaki yang menahan keseimbangan di samping bola, arahkan kaki kedepan, bahu dan pinggul lurus ke depan. Tekukkan sedikit lutut kaki, dan ayunkan kaki yang akan menendang ke belakang. Pada saat tubuh berada di atas bola, ayunkan kaki yang akan menendang ke depan, jaga kaki agar tetap lurus, tendang bagian tengah bola dengan bagian samping dalam kaki, pindahkan berat badan ke depan, dan lajutkan gerakan searah dengan bola. Pendapat lain dikemukakan oleh Justin Lhaksana (2006), definisi dalam melakukan passing kaki bagian dalam adalah: Passing menggunakan kaki bagian dalam adalah tempatkan kaki tumpu disamping bola, gunakan kaki bagian dalam untuk melakukan passing, kunci atau kuatkan tumit agar saat sentuhan dengan bola lebih kuat. Pada saat kaki dalam dari atas di arahkan ketengah bola (jantung) dan diteken kebawah agar bola tidak melambung, dan diteruskan dengan gerakan lanjutan, dimana setelah sentuhan dengan bola dalam melakukan passing ayunan kaki jangan dihentikan. Pada saat melakukan passing perkenaan kaki yang bersentuhan tepat ditengah-tengah bola agar alur jalannya bola mendatar di permukaan lapangan. Kesalahan umum yang biasa dilakukan pemain adalah melakukan passing dengan mengayunkan kaki secara menyilang di depan tubuh dan gerakan ini akan mengurangi kekuatan tendangan dan sering membuat passing menjadi lemah dan tidak efektif. Dengan demikian, yang dimaksud dengan passing mengunakan kaki bagian dalam, dalam penelitian ini adalah posisi kaki tumpu sejajar di samping bola, posisi kaki tumpu mengarah ke depan, lutut kaki tumpu sedikit ditekuk, posisi kaki tumpu menahan keseimbangan berat badan, posisi kaki ayun ditarik ke belakang dan diangkat, posisi kaki ayun digerakan mengenai bola, sentuhan kaki menggunakan kaki bagian dalam, bola ditendang pada bagian tengah bolanya, pada saat sentuhan dengan bola, posisi badan sejajar dengan kaki tumpu, lanjutkan gerakan kaki ayun searah dengan bola, diikuti berat badan ke depan.

Hasil belajar merupakan informasi yang menjadi indikator masukan dari proses belajar mengajar. Sedangkan proses biasanya berhubungan dengan metode proses belajar mengajar. Untuk memperoleh informasi tentang hasil belajar itu diperlukan penilaian bersifat formatif maupun sumatif. Menurut Supandi (1992) belajar adalah sesuatu yang masuk ke dalam proses belajar mengajar seperti siswa, guru, bahan ajar, media, sarana dan prasarana. Proses adalah kegiatankegiatan yang menggarap, upaya, mengubah masukan menjadi keluar, produk hasil out put dan hasil belajar akibat atau sebab dari proses belajar mengajar. Dengan demikian, yang dimaksud dengan hasil belajar adalah hasil yang diperoleh atau disebabkan dari adanya kegiatan proses belajar mengajar yang dirancang atau disusun oleh guru secara sistematis dengan dukungan alat bantu dan metode belajar. Tetapi jika proses tersebut tidak dilakukan dengan benar, maka suatu hasil belajar diperoleh dengan tidak maksimal. Ketidak berhasilan suatu hasil belajar dikarenakan seorang guru yang tidak mempergunakan pendekatan yang tidak sesuai dengan karakteristik siswa, seperti terlalu lelah atau kompleks.

Seorang pengajar harus bisa membuat pedoman tersendiri dalam mengatur 


\section{Volume 12 Nomor 1, Februari 2020}

pembelajaran demi suksesnya proses belajar mengajar. Menyampaikan nilai-nilai pendidikan serta pengembangan keterampilan dan pengetahuan yang dimana kesemuanya ini mengarah pada tujuan yang di harapkan. Dalam pendidikan jasmani mengajar harus mengetahui apakah siswa akan selalu siap dalam menerima pengajaran sehubungan dengan kemampuan melakukan gerakan dengan kekuatan ototnya. Pembelajaran adalah perubahan tingkah laku melalui pembelajaran yaitu perubahan yang lebih maju, lebih tinggi dan lebih kecil baik dari pada tingkah laku yang sedia ada sebelum aktivitas pembelajaran. Sedangkan Oemar Hamlik (2005) pembelajaran adalah suatu kombinasi yang tersusun yang meliputi unsurunsur manusiawi, material, fasilitas, perlengkapan dan prosedur yang saling mempengaruhi mencapai tujuan pembelajaran.

Didalam pembelajaran yang mana suatu kegiatan berasal atau berubah lewat reaksi dari suatu situasi yang dihadapi, dengan keadaan bahwa karakteristik-karakteristik dari perubahan aktivitas tersebut tidak dapat dijelaskan dengan dasar kecendrungankecendrungan reaksi asli, kematangan atau perubahan sementara dari suatu organisme. Untuk dapat menjalankan proses pembelajaran yang efektif sesuai dengan karakteristik peserta didik diperlukan sesuatu yang dapat dijadikan acuan dalam pembelajaran. Pada pembelajaran konvensional biasanya pendidik kurang mempergunakan berbagai metode, namun dalam pembelajaran modern seperti saat ini seorang pendidik lebih diarahkan untuk menggunakan berbagai metode dalam proses pembelajaran.

Metode yang digunakan oleh dosen di dalam mengajar tentunya tidak semua jenis metode yang digunakan dalam menyajikan bahan pelajaran pendidikan jasmani, seorang guru dapat menentukan metode mengajar yang dianggap tepat dan sesuai dengan materi ajar serta dapat meningkatkan keberhasilan dalam proses belajar mengajar. Dalam istilah metode berasal dari bahasa Yunani. Istilah ini berasal dari kata meta dan hodos. Meta diartikan sebagai seberang, sedangkan hodos diartikan sebagai jalan. Perkembangan selanjutnya metode didefinisikan menjadi menempatkan pelbagai hal atau menunjukan pelbagai kegiatan yang sangat menyenangkan.
Menurut John M. Mickleson, (1987) dalam (J. Matakupan, 1994/1995) Metode adalah suatu prosedur atau proses untuk memproleh suatu objek, sebagai suatu rencana yang sistematis dalam menyajikan sesuatu dalam pengajaran. Berarti metode sangat berpengaruh terhadap pembelajaran terhadap pembelajaran yang kemudian membentuk konsepsi mengenai metode belajar untuk dapat diterapkan dalam proses belajar.

Mahasiswa FIK UNM dalam hal melakukan tehnik passing masih banyak mengalami kendala, terutama pada saat perkenaan bola pada kaki terkhusus kaki bagian dalam. Ini dapat dilihat dengan masih banyaknya mahasiswa yang mempergunakan ujung kaki bagian dalam dan tumit bagian dalam. Dimana seharusnya perkenaan bola adalah bagian tengah sisi dalam kaki, ini bertujuan untuk mudah dalam penguasaan bola dan terkontrol. Selain itu dengan tepatnya bagian perkenaan bola maka pada saat mengumpan bisa terarah dan bola akan mengarah tepat kesasaran yang akan diberikan. Pada saat melaksanakan pembelajaran dengan mengandalkan kemampuan dosen dan mahasiswa yang merupakan salah satu matakuliah yang menyelenggarakan pembelajaran Futsal. Kegiatan ini dilaksanakan guna membina kemampuan dan minat siswa terhadap cabang olahraga Futsal. Minat yang besar perlu dibina agar kemampuan mereka meningkat dan dapat mencapai suatu pembelajaran yang optimal.

Pembelajaran metode keseluruhan dapat diartikan merupakan aktivitas gerak yang dilakukan secara keseluruhan dengan metode ini biasanya digunakan untuk melatih teknik dan gerakan yang sederhana atau apabila keseluruhan serangkaian gerak dari suatu teknik olahraga, tidak bisa dipecah menjadi bagian-bagian. Proses belajar mengajar guru harus dapat memilih metode mengajar yang tepat dan dapat diberikan peluang agar proses belajar mengajar terjadi secara efektif dalam kegiatan intruksional. Dalam penggunaan metode mengajar keseluruhan perlu diketahui tingkat kemampuan siswa terhadap materi yang akan disampaikan, juga perlu diketahui apakah materi tersebut relatif sederhana atau tidak. Hal ini dijelaskan oleh Harsono (1993) yang mengemukakan: Jika keterampilan dalam suatu cabang olahraga gerakannya secara relatif sederhana dan mudah dipahami 


\section{e-ISSN: 2657-0703 dan p-ISSN: 2085-5389}

atau dikuasai, keterampilan seperti itu dapat dilatih sebagai satuan yang utuh, tidak perlu dipilah pilah menjadi beberapa bagian dan dipelajari atau dilatih bagian demi bagian. Metode demikian disebut metode keseluruhan atau whole method. Dalam proses belajar mengajar terjadi interaksi antara guru dan murid yang menjadi syarat utama keberhasilan dari proses belajar mengajar. Siswa dapat berkembang dengan optimal berkat bimbingan dari guru, bimbingan ini adalah akibat suatu metode yang diterapkan dalam penyampaian materi pelajaran. Adapun anggapan bahwa bahan ajar itu seharusnya disampaikan secara utuh dan jangan sepotong-sepotong. Hal ini didasarkan pada anggapan bahwa dalam kehidupan sehari-hari belajar dimulai dari keseluruhan. Metode keseluruhan diartikan sebagai metode yang bersifat umum atau global yang menyajikan materi secara utuh, suatu cara pendekatan dalam mengajar dimana untuk menguasai gerakan, kepada mahasiswa diajarkan semua unsur rangkaian gerakan secara keseluruhan sekaligus. Hal ini ditegaskan oleh sugiyanto bahwa: Metode keseluruhan adalah cara pendekatan dalam mengajar dimana untuk menguasai suatu rangkaian gerakan, kepada atlet diajarkan semua unsur rangkaian gerakan secara keseluruhan dan dipraktekkan secara keseluruhan sekaligus pula. Dengan menggunakan metode keseluruhan mahasiswa diharapkan untuk berkonsentrasi pada gerakan secara keseluruhan. Jika siswa lebih mudah dan lebih cepat dapat menyesuaikan diri dengan metode keseluruhan ini, maka sebaiknya metode tersebut diterapkan. Hal ini dapat menghemat waktu siswa dalam mempelajari keterampilan secara keseluruhan. Adapun mengenai pelaksanaan metode keseluruhan pada proses belajar mengajar passing kaki bagian dalam ini adalah: (1) Dosen memberikan penjelasan tentang rangkaian gerakan passing kaki bagian dalam dari tahap awalan hingga akhiran, (2) Kemudian dosen mendemonstrasikan rangkaian gerakan tersebut berulang-ulang, (3) Selanjutnya siswa melakukan gerakan-gerakan passing kaki bagian dalam dari tahap awalan hingga akhiran secara berulang-ulang, dan (4) Dalam pengulangan-pengulangan yang dilakukan oleh siswa ini guru memberikan koreksi tentang kesalahan gerak yang dibuat oleh mahasiswa. Penggunaan metode keseluruhan mempunyai keuntungan seperti yang dikemukakan Nana Kosasih (1994): (1) Siswa mendapat insight yaitu pengertian yang diperoleh secara mendadak dari hubungan antara bagian-bagian tugas gerakan dengan tujuan yang ingin dicapai dalam situasi keseluruhan, (2) Siswa berusaha menghubungkan bagian yang satu dengan bagian yang lainnya sebanyak mungkin, (3) Bagian-bagian dari gerakan dipelajari tidak terlepas dari konteks keseluruhan tugas, (4) Siswa aktif terlibat dalam pemecahan masalah yang dihadapi, dan (5) Jika kemampuan secara menyeluruh benar-benar telah dikuasi maka akan terjadi transfer, bila suatu kemampuan telah dikuasai betul-betul maka dapat dipindahkan untuk kemampuan yang lain. Metode keseluruhan sangat cocok untuk mengajar keterampilan gerak yang sederhana. Metode ini memiliki efek yang baik dalam hal membangun motivasi siswa, karena mereka melihat langsung contoh gerakan yang utuh sehingga menimbulkan rasa ingin mencoba. Rasa ingin mencoba ini akan memungkinkan terjadinnya pengulangan-pengulangan gerakan yang utuh dilakukan oleh siswa. Dengan menggunakan metode keseluruhan mahasiswa berkonsentrasi pada gerakan secara keseluruhan, sehingga hal ini akan dapat menghemat waktu dalam mempelajari keterampilan secara keseluruhan.

Metode bagian menurut Beltasar Tarigan (1999/2000), tugas gerak dipelajari dan dilatih bagian demi bagian dan metode ini diterapkan apabila struktur gerak cukup kompleks sehingga diperkirakan dengan mempelajari bagian demi bagian akan memberikan hasil optimal. Jadi kegiatan yang paling strategis dalam pembelajaran adalah pemilihan metode mengajar bagian disesuaikan dengan kebutuhan. Dari sekian banyak metode mengajar yang dikenal diantaranya, yaitu metode mengajar bagian perbagian dan metode mengajar keseluruhan. Kedua metode ini cukup dikenal dan dapat diterapkan pada saat menetapkan strategi belajar mengajar Pendidikan Jasmani maupun untuk bidang studi yang lainnya. Dalam penggunaan metode bagian perbagian program pengajaran disajikan melalui bagianbagian terkecil yaitu bagian-bagian gerakan disusun menjadi unit-unit yang kecil sehingga setiap langkah pelajaran diharapkan dapat dikuasai karena gerakannya menjadi lebih sederhana. Hal ini sesuai dengan pendapat Sugiyanto bahwa metode bagian perbagian 


\section{Volume 12 Nomor 1, Februari 2020}

adalah cara pendekatan mengajar dimana untuk menguasai suatu rangkaian gerakan kepada atlet diajarkan bagian demi bagian dari unsur-unsur rangkaian gerakan untuk dipraktekkannya bagian demi bagian pula. Sedangkan menurut Beltasar Tarigan (1999/2000) bahwa metode bagian adalah tugas-tugas gerak dipelajari dan latihan bagian demi bagian.

Pelaksanaan metode mengajar bagian perbagian penyampaian materi pelajaran dilakukan secara bertahap, yaitu dengan jalan membagi-bagi materi gerak menjadi bagian yang lebih kecil atau sederhana. Metode ini biasanya digunakan untuk mempelajari materi gerak keterampilan yang kompleks agar mudah dipelajarinya maka bahan-bahan itu dibagi menjadi bagian-bagian yang lebih sederhana. Pada metode bagian perbagian siswa harus mengusai dahulu satu bagian, barulah dilanjutkan ke bagian yang lain dari yang mudah beralih ke yang sulit. Sehingga dapat diketahui bagian-bagian mana yang telah dikuasai dan bagian-bagian mana yang belum dikuasai oleh siswa, hal ini akan memudahkan guru dalam mengoreksi/ mencari bagian gerakan yang salah. Misalnya seorang guru mengajarkan gerakan sepak bola, kepada siswa tidak langsung diajarkan gerakan sepak bola secara utuh. Mula-mula siswa diajarkan gerakan ayunan kaki, tendangan bola dengan menyusur tanah dengan menggerakan kaki bagian dalam ke arah bola, sehingga dalam melakukan koreksi juga per bagian gerakan tersebut.

Penggunaan metode bagian perbagian diharapkan siswa dapat lebih mudah menerima maupun mempelajari materi pelajaran yang disampaikannya. Diharapkan dengan menggunakan metode bagian perbagian siswa lebih konsentrasi pada satu aspek saja dari keterampilan gerak keseluruhan. Metode mengajar bagian perbagian juga lebih tepat jika digunakan pada siswa yang kurang pandai, hal ini seperti yang disampaikan oleh Sugiyanto (1993): Jika keterampilan gerak merupakan kemampuan untuk melakukan gerakan secara efisien dan efektif, merupakan perwujudan dari kualitas koordinasi dan kontrol atas bagian-bagian tubuh yang terlibat dalam gerakan dan makin kompleks pola gerak yang harus dilakukan, makin kompleks juga koordinasi dan kontrol tubuh yang harus dilakukan dan ini berarti makin sulit juga untuk dilakukan. Penggunaan metode baik keseluruhan maupun bagian perbagian harus dipertimbangkan mengenai kompleksitas gerakan dan keeratan hubungan/rangkaian antar unsur gerakan. Semakin kompleks gerakan atau rumitnya unsur rangkaian gerakan, sebaiknya cendrung ke arah penggunaan metode bagian perbagian. Sedangkan semakin erat hubungan/rangkaian antar unsur, sebaiknya cendrung ke arah penggunaan metode keseluruhan.

\section{METODE PENELITIAN}

Penelitian ini dilakukan dengan menggunakan metode eksperimen yaitu dengan uji-t dengan melakukan Pretest dan Posttest design, yaitu dengan mengobservasi pada dua kelompok yang mendapat perlakuan yang berbeda. Penelitian ini dimulai pada bulan Maret 2018 berupa tes awal dan selesai pada bulan Agustus 2018 berupa tes akhir. Pertemuan berlangsung dengan frekuensi tiga kali dalam seminggu dengan jumlah pertemuan 12 kali. Teknik analis data yang dipergunakan untuk menguji hipotesis adalah uji-t, pada taraf signifikan $\alpha=0,05$, dimulai dengan menghitung nilai t-hitung untuk membandingkan dengan nilai t-tabel pada taraf signifikan $95 \%$.

\section{HASIL DAN PEMBAHASAN HASIL PENELITIAN}

1. Data tes awal metode keseluruhan terhadap proses hasil belajar mengumpan (passing) kaki bagian dalam.

Data hasil tes awal $\left(\mathrm{X}_{1}\right)$ diperoleh nilai terendah 15 sampai nilai tertinggi 24 dan tes akhir $\left(\mathrm{X}_{2}\right)$ nilai terendah 40 sampai nilai tertinggi 44 dengan mean of difference $\left(\mathrm{M}_{\mathrm{D}}\right)=$ 21,2 , nilai standar deviasi dari difference $\left(\mathrm{SD}_{\mathrm{D}}\right)=$ 2,8, nilai standar error dari mean difference $\left(\mathrm{SE}_{\mathrm{MD}}\right)=0,3$ kemudian dari hasil perhitungan selanjutnya diperoleh nilai $\mathrm{t}$ hitung $\left(\mathrm{t}_{\mathrm{h}}\right)=4$ dan $\mathrm{t}$ table $\left(\mathrm{t}_{\mathrm{t}}\right)=2$,14. Di bawah ini disajikan mengenai distribusi frekuensi dan grafik histrogam data hasil tes awal dan tes akhir metode keseluruhan terhadap proses hasil belajar passing kaki bagian dalam pada mahasiswa yang mengikuti pembelajaran Futsal di FIK UNM. 
Tabel 1.

Distribusi frekuensi tunggal tes awal $\left(\mathrm{X}_{1}\right)$

\begin{tabular}{|c|c|c|c|}
\hline No & Skor & Frekuensi & Prosentasi \\
\hline 1 & 15 & 1 & $6,66 \%$ \\
\hline 2 & 17 & 1 & $6,66 \%$ \\
\hline 3 & 18 & 1 & $6,66 \%$ \\
\hline 4 & 20 & 5 & $33,33 \%$ \\
\hline 6 & 22 & 3 & $20,00 \%$ \\
\hline 7 & 24 & 4 & $26,66 \%$ \\
\hline \multicolumn{2}{|c|}{ Jumlah } & $\mathbf{1 5}$ & $\mathbf{1 0 0} \%$ \\
\hline
\end{tabular}

Berdasarkan tabel di atas dapat disimpulkan bahwa frekuensi terbesar terdapat pada skor 20 berjumlah 5 orang dengan $33,33 \%$.
Di bawah ini digambarkan grafik diagram batang dari hasil tes awal $\left(\mathrm{X}_{1}\right)$ metode mengajar keseluruhan terhadap proses hasil belajar passing kaki bagian dalam.

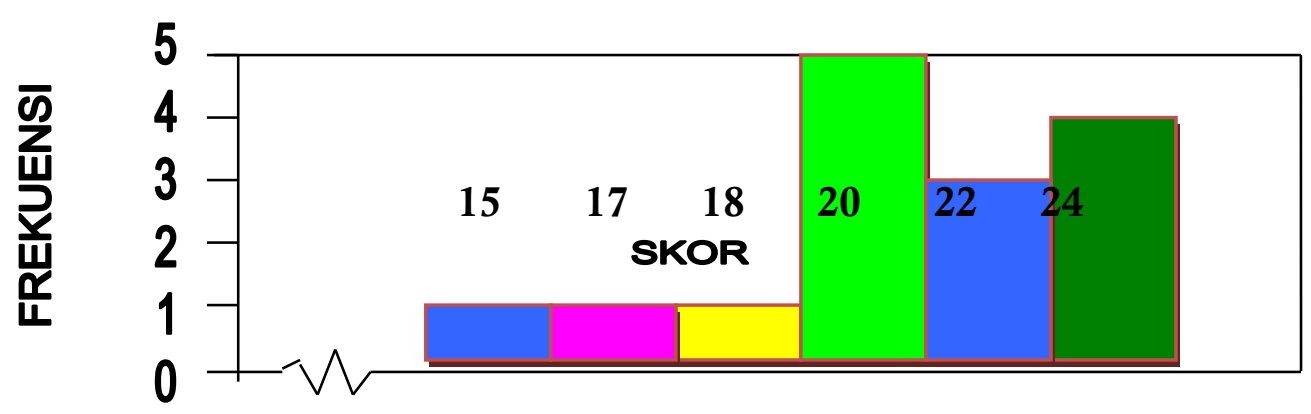

Gambar 1. Grafik diagram batang hasil tes awal metode keseluruhan

Tabel 2.

Distribusi frekuensi tunggal hasil tes akhir $\left(\mathrm{X}_{2}\right)$

\begin{tabular}{|c|c|c|c|}
\hline No & Skor & Frekuensi & Prosentasi \\
\hline 1 & 40 & 2 & $13,33 \%$ \\
\hline 2 & 41 & 2 & $13,33 \%$ \\
\hline 3 & 42 & 6 & $40 \%$ \\
\hline 4 & 43 & 4 & $26,66 \%$ \\
\hline 5 & 44 & 1 & $6,66 \%$ \\
\hline Jumlah & & 15 & $100 \%$ \\
\hline
\end{tabular}

Berdasarkan tabel di atas dapat disimpulkan bahwa frekuensi terbesar terdapat pada skor 42 berjumlah 6 orang dengan prosentasi $40 \%$.
Di samping digambarkan diagram batang dari data hasil tes akhir $\left(\mathrm{X}_{2}\right)$ metode keseluruhan dengan proses hasil belajar mengumpan (passing) kaki bagian dalam.

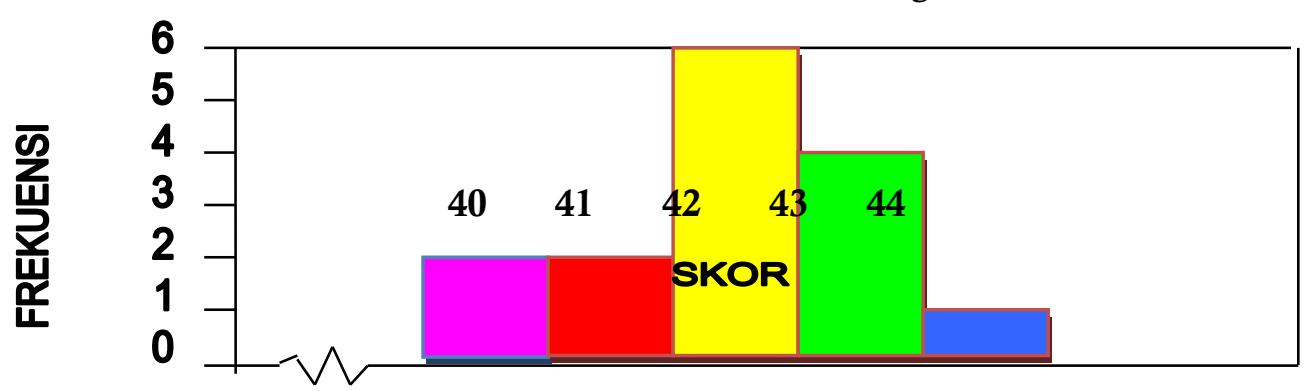




\section{Volume 12 Nomor 1, Februari 2020}

Gambar 2. Grafik diagram histogram hasil tes akhir metode Keseluruhan

2. Data hasil tes awal metode mengajar bagian perbagian terhadap proses hasil belajar mengumpan (passing) kaki bagian dalam dengan uji t.

Data hasil tes awal $\left(\mathrm{X}_{1}\right)$ metode mengajar bagian perbagian diperoleh nilai terendah 20 dan nilai tertinggi 28, sedangkan data tes akhir metode mengajar bagian perbagian $\left(\mathrm{X}_{2}\right)$ diperoleh nilai terendah 38 sampai nilai tertinggi 43. Dengan demikian mean of difference $\left(\mathrm{M}_{\mathrm{D}}\right)=15,4$. Nilai standar deviasi dari difference $\left(\mathrm{SD}_{\mathrm{D}}\right)=2,6$. Nilai standar error dari mean difference $\left(\mathrm{SE}_{\mathrm{MD}}\right)=0,7$. Kemudian dari hasil perhitungan selanjutnya diperoleh nilai $t$ hitung $\left(t_{h}\right)$ sebesar 3,7 dan $t$ table $\left(\mathrm{t}_{\mathrm{t}}\right)$ sebesar 2,14 .

Di samping disajikan mengenai distribusi frekuensi dan grafik batang data hasil tes awal dan tes akhir metode mengajar bagian perbagian terhadap proses hasil belajar passing kaki bagian dalam.

Tabel 3

Distribusi frekuensi tunggal hasil tes awal $\left(\mathrm{Y}_{1}\right)$

\begin{tabular}{|c|c|c|c|}
\hline No & Skor & Frekuensi & Prosentasi \\
\hline 1 & 20 & 1 & $6,66 \%$ \\
\hline 2 & 21 & 2 & $13,33 \%$ \\
\hline 3 & 22 & 1 & $6,66 \%$ \\
\hline 4 & 23 & 1 & $6,66 \%$ \\
\hline 5 & 25 & 2 & $13,33 \%$ \\
\hline 6 & 26 & 2 & $13,33 \%$ \\
\hline 7 & 27 & 2 & $13,33 \%$ \\
\hline 8 & 28 & 4 & $26,66 \%$ \\
\hline \multicolumn{2}{|c|}{ Jumlah } & $\mathbf{1 5}$ & $\mathbf{1 0 0} \%$ \\
\hline
\end{tabular}

Berdasarkan tabel di atas dapat disimpulkan bahwa frekuensi terbesar pada skor 28 berjumlah 4 orang dengan 26,66 \%. Di samping digambarkan diagram batang dari data hasil tes awal $\left(\mathrm{Y}_{1}\right)$ metode mengajar bagian perbagian terhadap proses hasil belajar mengumpan passing kaki bagian dalam.

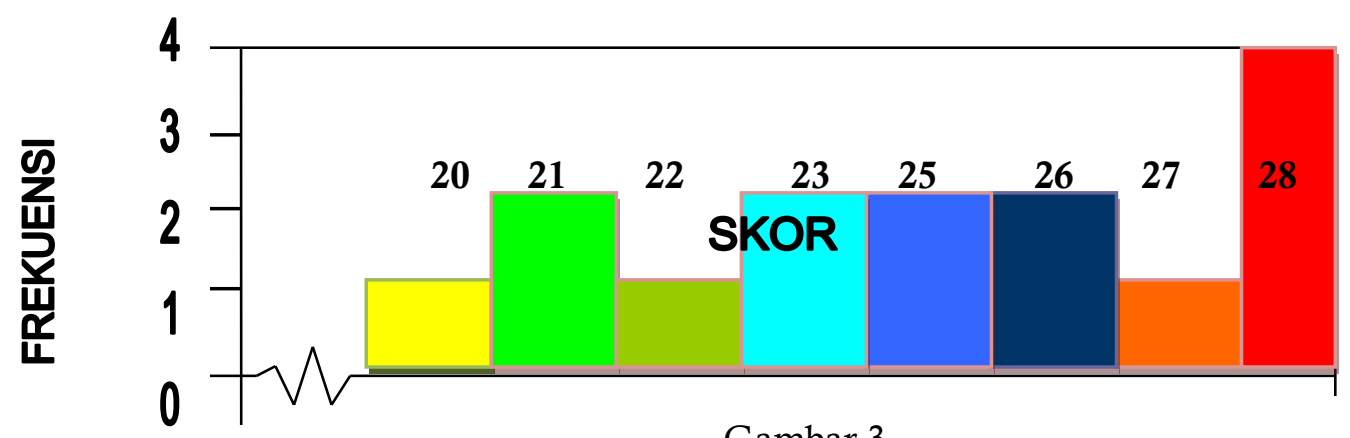

Gambar 3.

Grafik diagram histogram tes awal metode mengajar bagian Perbagian

Tabel 4.

Distribusi frekuensi tunggal tes akhir $\left(\mathrm{Y}_{2}\right)$

\begin{tabular}{|c|c|c|c|}
\hline No & Skor & Frekuensi & Prosentasi \\
\hline 1 & 38 & 2 & $13,33 \%$ \\
\hline 2 & 39 & 3 & $20,00 \%$ \\
\hline 3 & 40 & 2 & $13,33 \%$ \\
\hline 4 & 41 & 4 & $26,66 \%$ \\
\hline 5 & 42 & 2 & $13,33 \%$ \\
\hline
\end{tabular}




\begin{tabular}{|c|c|c|c|}
\hline 6 & 43 & 2 & $13,33 \%$ \\
\hline \multicolumn{2}{|c|}{ Jumlah } & $\mathbf{1 5}$ & $\mathbf{1 0 0 \%}$ \\
\hline
\end{tabular}

Berdasarkan tabel di atas dapat disimpulkan bahwa frekuensi terbesar terdapat pada skor 41 berjumlah 4 orang dengan 26,66 $\%$. Di bawah ini digambarkan grafik diagram lingkaran dari tes akhir $\left(\mathrm{Y}_{2}\right)$ metode mengajar bagian perbagian terhadap hasil belajar mengumpan passing kaki bagian dalam.

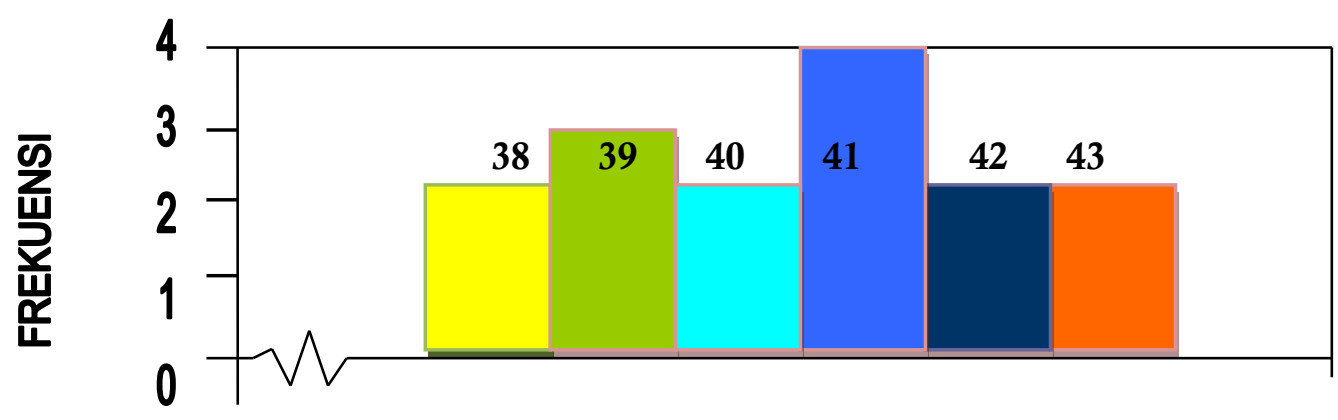

Gambar 4.

Grafik diagram histogram tes akhir metode mengajar bagian perbagian

\section{PEMBAHASAN}

1. Hasil tes awal dan tes akhir kelompok metode keseluruhan

Data yang terkumpul pada hasil tes awal dan akhir diperoleh $t_{\mathrm{h}}$ sebesar 4 yang kemudian dirujukan dengan $t$ table pada taraf kepercayaan $\alpha 0,05$ dan derajat kebebasan $\mathrm{N}$ $-1=14$, diperoleh $t_{t}=2,14$ yang berarti nilai $t_{\mathrm{h}}=4>\mathrm{t}_{\mathrm{t}}=2$, 14. Maka $\mathrm{H}_{\mathrm{o}}$ ditolak dan $\mathrm{H}_{1}$ diterima, berarti metode mengajar keseluruhan efektif dalam meningkatkan proses hasil belajar mengumpan (passing) kaki bagian dalam pada mahasiswa yang mengikuti pembelajaran Futsal di FIK UNM.

\section{Hasil tes awal dan tes akhir kelompok metode mengajar bagian perbagian}

Data yang terkumpul dari hasil tes awal dan akhir diperoleh $t_{\mathrm{h}}$ sebesar 3,7 yang kemudian dirujukan dengan $\mathrm{t}$ table pada taraf kepercayaan $\alpha 0,05$ dan derajat kebebasan $\mathrm{N}$ $-1=14$, diperoleh $t_{t}=2,14$ yang berarti nilai $t_{h}=3,7>t_{t}=2$, 14. Maka $\mathrm{H}_{\mathrm{o}}$ ditolak dan $\mathrm{H}_{1}$ diterima, berarti metode mengajar bagian perbagian efektif dalam meningkatkan proses hasil belajar mengumpan (passing) kaki bagian dalam pada mahasiswa yang mengikuti pembelajaran Futsal di FIK UNM.

\section{Hasil akhir kelompok metode keseluruhan dengan metode mengajar bagian perbagian.}

Data yang ada dari hasil tes akhir metode keseluruhan dan hasil akhir metode mengajar bagian perbagian terhadap proses hasil belajar mengumpan (passing) kaki bagian dalam adalah sebagai berikut : hasil perhitungan tes akhir metode keseluruhan diperoleh nilai rata-rata $(\mathrm{x})=40.4$, nilai standar deviasi $\left(\mathrm{S}_{\mathrm{D}}\right)$ sebesar $=1.6$, nilai standar error mean $\left(\mathrm{SD}_{\mathrm{MD}}\right)=0.4$, sedangkan nilai standar error mean $\left(\mathrm{SE}_{\mathrm{MD}}\right)$ antara variabel $(\mathrm{x})$ dan variabel $(\mathrm{Y})$ diperoleh hasil $=0,5$. dan hasil perhitungan tes akhir metode mengajar bagian perbagian diperoleh nilai rata-rata $(\mathrm{x})$ $=42$, nilai standar deviasi $\left(\mathrm{S}_{\mathrm{D}}\right)$ sebesar $=1.1$, nilai standar error mean $\left(\mathrm{SD}_{\mathrm{MD}}\right)=0.3$, Perhitungan selanjutnya diperoleh nilai $t$ hitung $\left(t_{h}\right)$ sebesar 3.2 dan nilai t-tabel $\left(t_{t}\right)$ sebesar dan nilai $t$ tabel $\left(t_{t}\right)$ sebesar 2.05 dengan taraf signifikann 5\%. Dengan demikian nilai $t_{h} 3.2>t_{t}$ 2.05. Maka $H_{o}$ ditolak $\mathrm{H}_{1}$ diterima maka metode keseluruhan lebih efektif dari pada metode mengajar bagian perbagian terhadap hasil belajar mengumpan (passing) kaki bagian dalam pada mahasiswa yang mengikuti pembelajaran Futsal di FIK UNM.

\section{SIMPULAN DAN SARAN}

Berdasarkan menjelaskan bahwa mengajar tersebut, keseluruhan lebih hasil penelitian dari kedua metode metode mengajar efektif pengaruhnya 
dibandingkan metode mengajar bagian perbagian dalam meningkatkan hasil belajar mengumpan (passing) kaki bagian dalam pada mahasiswa yang mengikuti pembelajaran Futsal di FIK UNM.

Berdasarkan kesimpulan dari hasil penelitian ini penulis menyarankan agar:

1. Dosen menggunakan metode keseluruhan dalam meningkatkan hasil belajar yang optimal, dalam menyusun materi mengumpan (Passing) kaki bagian dalam pada mahasiswa yang mengikuti pembelajaran Futsal.

2. Mahasiswa Fakultas Ilmu Keolahragaan khususnya Jurusan Pendidikan Jasmani, Kesehatan dan Rekreasi dapat meneliti metode mengajar yang lain.

\section{DAFTAR RUJUKAN}

Beltasar Tarigan. (1999/2000). Penjaskes Adaptif. Jakarta: Departemen Pendidikan dan Kebudayaan Direktorat Jenderal Pendidikan Dasar dan Menengah Bagian Proyek Penataran Guru SLTP Setara D-III.

Gill Harvey. (2003). Teknik Mengoper dan Menembak. Jakarta: PT. Gapuramitra Sejati.

Harsono. (1993). Prinsip-Prinsip Latihan, Jakarta: KONI, Pusat Pendidikan Dan Penataran.

J. Matakupan. (1994/1995). Strategi Belajar Mengajar Pendidikan Jasmani dan Kesehatan. Jakarta: Dinas Pendidikan dan Pengajaran DKI Jakarta Proyek Pembinaan Pendidikan Extrakulikuler.

John D. Tenang. (2008). Mahir Bermain Futsal, Dilengkapi Teknik dan Strategi Bermain. DAR! Mizan

Joseph A. Luxbacher. (1997). Sepakbola, Jakarta: PT. Raja Grafindo Persada.

Justin Lhaksana. (2006). Futsal Coaching Clinik Kelme Futsalismo. Jakarta: Difamata Sport EO.

Kadir Yusuf. (1982). Sepakbola Indonesia. Jakarta: PT. Gramedia.

Murhananto. (2006). Dasar-dasar Permainan Futsal, (sesuai dengan peraturan FIFA). Jakarta: Kawan Pustaka.

Nana Kosasih. 1994. Pengaruh Metode Belajar Keseluruhan Bagian Dan Bagian Keseluruhan Terhadap Hasil Belajar Panahan Bagi Mahasiswa Yang Mempunyai Kekuatan Otot Punggung
Yang Berbeda. Jakarta: Lembaga Penelitian IKIP Jakarta.

Oemar Hamlik. (2005). Kurikulum dan Pembelajaran. Jakarta: Bumi Aksara.

Suharjanto. 2007. Taktik, Strategi dan Teknik Dasar Futsal, (Jakarta: Difamata Sport EO.

Sugiyanto. (1993). Belajar Gerak. Jakarta: Koni Pusat Pendidikan dan Penataran.

Supandi. (1992). Strategi Belajar Mengajar Pendidikan Jasmani dan Kesehatan. Jakarta: Depdikbut Dirjen Pendidikan Tinggi Proyek Pembinaan Tenaga Kependidikan. 